\title{
Relationship of severity of subacute ruminal acidosis to rumen fermentation, chewing activities, sorting behavior, and milk production in lactating dairy cows fed a high-grain diet
}

\author{
X. Gao and M. Oba ${ }^{1}$ \\ Department of Agricultural, Food and Nutritional Science, University of Alberta, Edmonton, AB T6G 2P5, Canada
}

\begin{abstract}
The objectives of the current study were to evaluate the variation in severity of subacute ruminal acidosis (SARA) among lactating dairy cows fed a high-grain diet and to determine factors characterizing animals that are tolerant to high-grain diets. Sixteen ruminally cannulated late-lactating dairy cows (days in milk = $282 \pm 33.8$; body weight $=601 \pm 75.9 \mathrm{~kg}$ ) were fed a high-grain diet consisting of $35 \%$ forage and $65 \%$ concentrate mix. After $17 \mathrm{~d}$ of diet adaptation, chewing activities were monitored for a $24-\mathrm{h}$ period and ruminal $\mathrm{pH}$ was measured every $30 \mathrm{~s}$ for $72 \mathrm{~h}$. Acidosis index, defined as the severity of SARA (area of $\mathrm{pH}<5.8$ ) divided by dry matter intake (DMI), was determined for individual animals to assess the severity of SARA normalized for a feed intake level. Although all cows were fed the same diet, minimum $\mathrm{pH}$ values ranged from 5.16 to 6.04 , and the acidosis index ranged from 0.0 to $10.9 \mathrm{pH} \cdot \mathrm{min} / \mathrm{kg}$ of DMI. Six cows with the lowest acidosis index $(0.04 \pm 0.61 \mathrm{pH} \cdot \mathrm{min} / \mathrm{kg})$ and 4 with the highest acidosis index $(7.67 \pm 0.75 \mathrm{pH} \cdot \mathrm{min} / \mathrm{kg})$ were classified as animals that were tolerant and susceptible to the high-grain diet, respectively. Total volatile fatty acid concentration and volatile fatty acid profile were not different between the groups. Susceptible animals sorted against long particles, whereas tolerant animals did not (sorting index $=87.6$ vs. 97.9, respectively). However, the tolerant cows had shorter total chewing time (35.8 vs. $45.1 \mathrm{~min} / \mathrm{kg}$ of DMI). In addition, although DMI, milk yield, and milk component yields did not differ between the groups, milk urea nitrogen concentration was higher for tolerant cows compared with susceptible cows (12.8 vs. $8.6 \mathrm{mg} / \mathrm{dL}$ ), which is possibly attributed to less organic matter fermentation in the rumen of tolerant cows. These results suggest that a substantial variation exists in the severity of SARA among lactating dairy cows fed the same highgrain diet, and that cows tolerant to the high-grain diet
\end{abstract}

Received September 3, 2013.

Accepted January 12, 2014.

${ }^{1}$ Corresponding author: Masahito.Oba@ales.ualberta.ca might be characterized by less sorting behavior but less chewing time, and higher milk urea nitrogen concentration.

Key words: subacute ruminal acidosis, chewing activity, sorting behavior, milk urea nitrogen

\section{INTRODUCTION}

Subacute ruminal acidosis (SARA) is a prevalent metabolic disorder found in high-producing dairy herds, mainly caused by feeding excessively fermentable diets. One field survey in the United States indicated that incidences of SARA were $19 \%$ in early-lactation dairy cows and $26 \%$ in mid-lactation cows (Garret et al., 1997). Subacute ruminal acidosis accounts for substantial economic losses in the dairy industry due to its association with decreased feed intake, liver abscesses (Nagaraja and Lechtenberg, 2007), milk fat depression (Kleen et al., 2003), diarrhea, laminitis (Nocek, 1997), and increased bacterial endotoxins and inflammation (Khafipour et al., 2009). Diet formulation strategies to reduce the incidence of SARA have been extensively studied; however, some cows in a herd still experience SARA even if suggested strategies are implemented. Previous studies indicated that huge variations exist in the extent of severity of rumen acidosis among beef steers (Brown et al., 2000; Schlau et al., 2012), primiparous dry cows (Penner et al., 2007), and sheep (Penner et al., 2009) fed identical diets. But, to our knowledge, similar data have not been demonstrated for lactating dairy cows.

Ruminal $\mathrm{pH}$ is determined by the balance between acid production in the rumen and acid removal from the rumen by absorption through rumen epithelial cells, neutralization with buffers, and passage to lower digestive tracts (Allen, 1997). Therefore, the variation in the tolerance to the high-grain diet could be due to variations in any single or any combination of these 4 factors (Penner et al., 2009). Penner et al. (2009) demonstrated that ruminal epithelial cells from acidosisresistant sheep had a greater capability to absorb VFA in vitro, which suggested that rate of VFA absorption might affect the extent of tolerance to the high-grain 
diet in vivo. Schlau et al. (2012) found that acidosisresistant steers had lower total VFA concentrations in the ruminal fluid compared with acidosis-susceptible steers, which indicated that higher ruminal $\mathrm{pH}$ in tolerant animals might be due to faster VFA absorption, lower VFA production, or both. Besides VFA production and absorption, neutralization is another main factor contributing to regulation of rumen $\mathrm{pH}$. Chewing activities are expected to stimulate salivary secretion (Church, 1988), and Allen (1997) estimated that approximately $37 \%$ of protons are removed from the rumen via neutralization by salivary buffers. Therefore, we hypothesized that variation in chewing activities is related to tolerance or susceptibility to high-grain diets.

It has been suggested that milk fat depression is commonly associated with SARA (Kleen et al., 2003; Oetzel, 2003; Stone, 2004). A field study on a large dairy farm found that SARA reduced milk fat production by $0.3 \%$ (Stone, 1999). In addition, experimentally induced SARA, either by adding grains to the diet or by replacing alfalfa hay with alfalfa pellets, reduced milk fat concentration (Fairfield et al., 2007; Khafipour et al., 2007). Moreover, Allen (1997) and Enemark et al. (2004) reported a positive relationship between milk fat concentration and ruminal $\mathrm{pH}\left(\mathrm{R}^{2}=0.39\right.$ and 0.31 for each study, respectively). Therefore, we hypothesized that cows that are tolerant to highly fermentable diets have higher milk fat content compared with cows that are susceptible to high-grain diets, and expected that milk fat content might be a noninvasive indicator to identify the tolerant and susceptible cows on farm. The objectives of the current study were to evaluate the variation in severity of SARA among lactating dairy cows fed a high-grain diet and to determine factors characterizing cows that are tolerant and susceptible to high-grain diets.

\section{MATERIALS AND METHODS}

All experimental procedures used in this study were approved by the University of Alberta Research Centre Animal Care Committee and conducted according to the guidelines of the Canadian Council of Animal Care (Ottawa, Ontario, Canada).

\section{Animals, Diets, and Experimental Design}

Sixteen (8 primiparous and 8 multiparous) ruminally cannulated lactating Holstein cows (DIM $=282 \pm 33.8$; $\mathrm{BW}=601 \pm 75.9 \mathrm{~kg}$; mean $\pm \mathrm{SD}$ ) were used in this study. Cows were fed a diet containing $35 \%$ forage and $65 \%$ concentrate mix (Table 1 ) ad libitum for $21 \mathrm{~d}$, consisting of a 17 -d diet adaptation period and a $4-d$ data and sample collection period.
Table 1. Ingredient, chemical composition, and particle size distribution of the diet

\begin{tabular}{lc}
\hline Item & Measurement \\
\hline Ingredient, \% DM & \\
Barley silage & 30.0 \\
Barley grain, dry rolled & 25.0 \\
Corn grain, ground & 20.0 \\
Canola meal & 7.35 \\
Corn gluten meal & 5.26 \\
Alfalfa hay & 5.0 \\
Beet pulp & 3.96 \\
Vegetable oil & 1.0 \\
Mineral and vitamin mix ${ }^{1}$ & 2.43 \\
Nutrient composition, \% DM & \\
DM & 60.8 \\
Ash & 7.95 \\
CP & 15.9 \\
NDF & 25.6 \\
Starch & 31.1 \\
Ether extract & 4.0 \\
NFC & 49.8 \\
Forage NDF & 14.3 \\
Particle size distribution, \% as fed & \\
>19 mm & 20.2 \\
19-8 mm & 24.3 \\
1.18-8 mm & 39.4 \\
Physical effectiveness factor ${ }^{2}$ & 16.1 \\
Phy & 44.5 \\
\hline
\end{tabular}

${ }^{1}$ Contained $15.7 \% \mathrm{Ca}, 3.32 \% \mathrm{P}, 14.1 \% \mathrm{Na}, 21.8 \% \mathrm{Cl}, 5.70 \% \mathrm{Mg}, 0.23 \%$ $\mathrm{S}, 0.06 \% \mathrm{~K}, 2,867.4 \mathrm{mg} / \mathrm{kg}$ of $\mathrm{Fe}, 468.7 \mathrm{mg} / \mathrm{kg}$ of Cu, $902.8 \mathrm{mg} / \mathrm{kg}$ of $\mathrm{Mn}, 11.2 \mathrm{mg} / \mathrm{kg}$ of Co, $718.0 \mathrm{mg} / \mathrm{kg}$ of Zn, $7.08 \mathrm{mg} / \mathrm{kg}$ of Se, $21.0 \mathrm{mg} /$ $\mathrm{kg}$ of I, $442.8 \mathrm{kIU} / \mathrm{kg}$ of vitamin A, $45.0 \mathrm{kIU} / \mathrm{kg}$ of vitamin D, and $1,449.9 \mathrm{kIU} / \mathrm{kg}$ of vitamin E.

${ }^{2}$ Determined as the proportion of particles retained on 19- and 8-mm sieves on an as-fed basis (Lammers et al., 1996).

Cows were housed individually in tiestalls bedded with wood shavings, fed the experimental diet as a TMR once daily at $0900 \mathrm{~h}$, and had free access to water. Feed was offered at 105 to $110 \%$ of actual feed intake of the previous day. Samples of TMR and feed ingredients were collected daily during sample collection period. The weight of feed offered and refused was recorded daily on d 19, 20, and 21 of the study, and $12.5 \%$ of the total daily refusal from each cow was composited to yield one sample per cow per period. The DM concentration of barley silage and alfalfa hay was determined twice weekly and diet formulation was adjusted if necessary. Cows were weighed after the morning milking on 2 consecutive days immediately before the start of experiment. Cows were milked twice daily at 0400 and 1500 h. Milk was sampled from both a.m. and p.m. milkings on d 19, 20, and 21 of the study.

\section{Rumen $\mathrm{pH}$ and Rumen Fermentation}

Ruminal $\mathrm{pH}$ was measured in the ventral sac every $30 \mathrm{~s}$ continuously for $72 \mathrm{~h} \mathrm{(d} \mathrm{19-21)} \mathrm{using} \mathrm{the} \mathrm{pH}$ measurement system evaluated by Penner et al. (2006). Minimum, mean, and maximum $\mathrm{pH}$, and duration and 
area below pH 5.8 were determined for each cow daily and averaged over 3 -d periods. These data were used to determine acidosis index (area under $\mathrm{pH} 5.8$ divided by DMI; Penner et al., 2009) to assess the severity of SARA normalized for a feed consumption level.

Rumen fluid was collected from cranial, ventral, and caudal sacs, then combined and strained through a perforated screen (Peetex, Sefar Canada Inc., Scarborough, ON, Canada; pore size $=355 \mu \mathrm{m}$ ) every $9 \mathrm{~h}$ over a 72 -h period. The samples were centrifuged at $3,000 \times g$ at $4^{\circ} \mathrm{C}$ for $20 \mathrm{~min}$ immediately after collection, and the supernatants were stored at $-20^{\circ} \mathrm{C}$ until analysis. Rumen fluid samples were composited to yield one sample per cow for further analysis. Ruminal fluid samples were analyzed for VFA profile by gas chromatography according to the method described by Khorasani et al. (1996). Rumen ammonia-N concentration was determined as described by Fawcett and Scott (1960) using a plate reader (SpectraMax 190, Molecular Devices Corp., Sunnyvale, CA).

\section{Chewing Activity and Sorting Behavior}

Chewing activities were directly monitored for $24 \mathrm{~h}$ on $\mathrm{d} 18$. Eating and ruminating activities were recorded every 5 min and each activity was assumed to last for the entire 5-min interval between observations, as described previously (Beauchemin et al., 2003; Krause et al., 2003; Zhang et al., 2010). Total chewing time was calculated as the sum of eating time and ruminating time.

Particle size distribution of the TMR and orts were determined using a Penn State Particle Separator with 3 sieves (aperture size of 19, 8, and $1.18 \mathrm{~mm}$ ). Sorting index was calculated as the ratio of actual intake to predicted intake for particles retained on each sieve of the separator (Leonardi and Armentano, 2003). A sorting index of 100 , greater than 100 , and less than 100 indicate no sorting, selective consumption, and selective refusals, respectively. Physically effective factor was determined as the proportion of particles retained on 19- and 8-mm sieves (Lammers et al., 1996).

\section{Blood Collection}

Blood samples were collected every $18 \mathrm{~h}$ over a 72 -h (d 19-21) period from the coccygeal vessels into tubes containing sodium heparin (Fisher Scientific Company; Nepean, ON, Canada). Samples were centrifuged at $3,000 \times g$ at $4^{\circ} \mathrm{C}$ for 20 min immediately after collection, and plasma was harvested and stored at $-20^{\circ} \mathrm{C}$ until analysis. Plasma samples were composited to yield one sample per cow for further analysis.
Plasma samples were analyzed for glucose concentration using a glucose oxidase and peroxidase enzyme (Sigma, St. Louis, MO) and dianisidine dihydrochloride (Sigma) procedure. Absorbance was determined by a plate reader (SpectraMax 190) at a wavelength of 450 nm. Plasma BHBA concentration was measured by the enzymatic oxidation of BHBA to acetoacetate using 3-hydroxybutyrate dehydrogenase (Roche, Mississauga, ON, Canada) followed by determination of reduction of $\mathrm{NAD}^{+}$to NADH at a wavelength of $340 \mathrm{~nm}$. Commercial kits were used to determine concentrations of plasma NEFA (Wako Chemicals USA Inc., Richmond, VA) and insulin (Coat-a-Count kit, Diagnostic Products Corp., Los Angeles, CA).

\section{Milk Composition}

Milk samples were analyzed for milk fat, CP, lactose, and MUN by infrared spectroscopy (AOAC International, 2002; method 972.16; MilkoScan 605, Foss North America, Brampton, ON, Canada) at the Alberta Central Milk Testing Laboratory (Edmonton, AB, Canada).

\section{Statistical Analysis}

Effect of parity was originally tested using the PROC TTEST procedure of SAS (version 9.2, SAS Institute Inc., Cary, NC), but it was not included in the final model as significant parity effects were not observed for ruminal $\mathrm{pH}$ variables (Table $2, P>0.05$ ). Values of mean $\pm 0.5 \times \mathrm{SD}$ of acidosis index were used as criteria to identify groups of extreme animals (i.e., tolerant and susceptible animals), and all response variables were evaluated for the group effect using PROC TTEST. In addition, sorting index data were tested to determine if they are different from 100 by using PROC TTEST. The PROC REG procedure was used to determine the relationships between sorting index versus minimum ruminal $\mathrm{pH}$, sorting index versus acidosis index, and MUN versus acidosis index. Significance was declared at $P<0.05$ and tendency was declared at $0.05<P<$ 0.10 .

\section{RESULTS}

No differences were observed in minimum, mean, and maximum ruminal $\mathrm{pH}$ between primiparous cows and multiparous cows, as well as duration of $\mathrm{pH}$ below 5.8 and area of $\mathrm{pH}$ below $5.8(P>0.10$; Table 2$)$. Although a tendency for higher DMI for multiparous cows was noted, acidosis index was not different between primiparous and multiparous cows. 
Table 2. Comparison of BW, DMI, and pH measurements between primiparous and multiparous cows

\begin{tabular}{lcccc}
\hline Variable & Primiparous & Multiparous & SE & $P$-value \\
\hline BW, kg & 564 & 639 & 23.9 & 0.04 \\
DMI, kg/d & 19.4 & 22.1 & 1.02 & 0.08 \\
Ruminal pH & & & & \\
Nadir & 5.48 & 5.61 & 0.10 & 0.38 \\
Mean & 6.20 & 6.34 & 0.07 & 0.19 \\
Maximum & 6.85 & 6.97 & 0.05 & 0.15 \\
Duration $\mathrm{pH}<5.8, \mathrm{~min} / \mathrm{d}$ & 298 & 154 & 78.3 & 0.21 \\
Area $\mathrm{pH}<5.8, \mathrm{pH} \times \mathrm{min} / \mathrm{d}$ & 68.1 & 27.7 & 20.4 & 0.18 \\
Acidosis index, $\mathrm{pH} \times \mathrm{min} / \mathrm{kg}$ & 3.84 & 1.21 & 1.12 & 0.12 \\
\hline
\end{tabular}

Among all cows, minimum ruminal $\mathrm{pH}$, mean $\mathrm{pH}$, and duration and area of $\mathrm{pH}$ below 5.8 ranged from 5.16 to $6.04,5.94$ to 6.57 , and 0 to $606 \mathrm{~min} / \mathrm{d}$ and 0 to $193 \mathrm{pH}$ $\times \mathrm{min} / \mathrm{d}$, respectively. The acidosis index ranged from 0.0 to $10.9 \mathrm{pH} \times \mathrm{min} / \mathrm{kg}$ of DMI. Acidosis index of 6 cows was lower than the value of mean $-0.5 \times \mathrm{SD}$, and that of 4 cows was higher than the value of mean +0.5 $\times \mathrm{SD}$, and they were classified as animals tolerant and susceptible to the high-grain diet, respectively.

\section{Ruminal $\mathrm{pH}$ and VFA Profile}

No differences were observed in BW and DMI between tolerant and susceptible animals $(P>0.10$; Table $3)$. However, the minimum (5.83 vs. $5.22 ; P<0.01)$ and mean ruminal $\mathrm{pH}(6.47$ vs. $6.02 ; P<0.01)$ were higher for tolerant animals compared with susceptible animals, whereas maximum $\mathrm{pH}$ values were not different between the groups. Duration (10.1 vs. $556 \mathrm{~min} / \mathrm{d}$; $P<0.01)$ and area of $\mathrm{pH}$ below $5.8(0.86$ vs. $140 \mathrm{pH} \times$ $\mathrm{min} / \mathrm{d} ; P<0.01)$ were lower in tolerant animals. Acidosis index was lower in tolerant animals (0.04 vs.7.67 $\mathrm{pH} \times \min / \mathrm{kg} ; P<0.01)$. Total VFA concentration and VFA profile were not different between the groups $(P$ $>0.10$; Table 4 ), whereas the concentration of rumen $\mathrm{NH}_{3}-\mathrm{N}$ tended to be higher for tolerant cows $(P=0.06)$.

\section{Sorting Behavior and Chewing Activity}

Both groups sorted for short particles, but susceptible animals sorted to a greater extent (sorting index =
105 vs. $102 ; P=0.05$; Table 5). Moreover, susceptible animals sorted against long particles, whereas tolerant animals did not (sorting index $=87.6$ vs. $97.9 ; P=$ 0.05). Eating, ruminating and total chewing time (minutes per day) were not different between tolerant and susceptible animals $(P>0.10$; Table 6$)$. However, the tolerant cows had shorter ruminating time per unit of DMI (25.4 vs. $33.2 \mathrm{~min} / \mathrm{kg}$ of DMI; $P=0.05$ ) and total chewing time per unit of DMI (35.8 vs. $45.1 \mathrm{~min} / \mathrm{kg}$ of DMI; $P<0.05)$.

\section{Milk Production}

No differences were observed in milk yield and milk component yields between tolerant and susceptible cows $(P>0.10$; Table 7$)$. In addition, concentrations of milk fat, protein, and lactose did not differ between the groups. However, concentration of MUN was higher for tolerant animals compared with susceptible animals (12.8 vs. $8.6 \mathrm{mg} / \mathrm{dL} ; P<0.05)$.

\section{Plasma Metabolites and Hormones}

Plasma glucose, insulin, BHBA, and NEFA concentrations were not different between tolerant and susceptible cows $(P>0.10$; Table 8).

\section{DISCUSSION}

Subacute ruminal acidosis is a metabolic disorder particularly prevalent in high-producing dairy herds.

Table 3. Comparison of BW, DMI, and pH measurements between tolerant and susceptible cows

\begin{tabular}{lcccc}
\hline Variable & Tolerant & Susceptible & SE & $P$-value \\
\hline $\mathrm{BW}, \mathrm{kg}$ & 622 & 566 & 36.2 & 0.31 \\
DMI, kg/d & 21.6 & 18.8 & 1.31 & 0.17 \\
Ruminal pH & & & & \\
Nadir & 5.83 & 5.22 & 0.06 & $<0.01$ \\
Mean & 6.47 & 6.02 & 0.04 & $<0.01$ \\
Maximum & 6.98 & 6.88 & 0.08 & 0.38 \\
Duration $\mathrm{pH}<5.8, \mathrm{~min} / \mathrm{d}$ & 10.1 & 556 & 23.3 & $<0.01$ \\
Area $\mathrm{pH}<5.8, \mathrm{pH} \times \mathrm{min} / \mathrm{d}$ & 0.855 & 140 & 9.92 & $<0.01$ \\
Acidosis index, $\mathrm{pH} \times \mathrm{min} / \mathrm{kg}$ & 0.037 & 7.67 & 0.67 & $<0.01$ \\
\hline
\end{tabular}


Table 4. Comparison of ruminal VFA profile and rumen $\mathrm{NH}_{3}-\mathrm{N}$ between tolerant and susceptible cows

\begin{tabular}{lcccr}
\hline Variable & Tolerant & Susceptible & SE & $P$-value \\
\hline Total VFA, $\mathrm{m} M$ & 126 & 131 & 7.82 & 0.66 \\
Acetate, $\mathrm{mol} / \mathrm{mo} \mathrm{mol}$ & 54.2 & 53.5 & 1.91 & 0.81 \\
Propionate, $\mathrm{mol} / 100 \mathrm{~mol}$ & 26.4 & 29.3 & 2.08 & 0.36 \\
Isobutyrate, $\mathrm{mol} / 100 \mathrm{~mol}$ & 1.07 & 0.65 & 0.04 & $<0.01$ \\
Butyrate, $\mathrm{mol} / 100 \mathrm{~mol}$ & 13.8 & 11.5 & 1.25 & 0.24 \\
Isovalerate, $\mathrm{mol} / 100 \mathrm{~mol}$ & 1.97 & 1.26 & 0.18 & 0.03 \\
Valerate, $\mathrm{mol} / 100 \mathrm{~mol}$ & 2.08 & 2.36 & 0.19 & 0.33 \\
Caproate, $\mathrm{mol} / 100 \mathrm{~mol}$ & 0.56 & 1.48 & 0.46 & 0.20 \\
Acetate:propionate & 2.13 & 1.89 & 0.23 & 0.48 \\
Rumen $\mathrm{NH}_{3}-\mathrm{N}, \mathrm{mg} / \mathrm{dL}$ & 9.38 & 4.66 & 1.51 & 0.06 \\
\hline
\end{tabular}

The risk of SARA is greater for early- and mid-lactation cows compared with late-lactation cows due to feeding highly fermentable diets and greater feed intake. Garret et al. (1997) indicated that incidences of SARA were $19 \%$ for early-lactation dairy cows and $26 \%$ for mid-lactation cows. However, late-lactation cows were used in the current study due to the animal availability. Although early- or mid-lactation cows would be a better model for the current study, a substantial variation in the severity of SARA was detected among late lactating cows fed the same high-grain diet, which is consistent with previous studies using different type of animals. Brown et al. (2000) found that, when 5 steers were intraruminally dosed with steam-flaked corn, average ruminal $\mathrm{pH}$ ranged from 4.26 to 5.63. In another steer study by Schlau et al. (2012), 17 beef steers were force-fed the same diet consisting of $85 \%$ grain through rumen cannulas and the acidosis index ranged from 4.0 to $96.5 \mathrm{pH} \times \mathrm{min} / \mathrm{kg}$ among the animals. In addition, when Penner et al. (2007) provided additional concentrate to primiparous cows during the periparturient period, they found high SEM for ruminal $\mathrm{pH}$ variables within the treatment; for example, SEM was $30.7 \%$ of the mean for the area of $\mathrm{pH}<5.8$ (mean \pm SEM; 766 $\pm 235 \mathrm{pH} \times \mathrm{min})$. The high $\mathrm{SEM}$ values indicated that some cows within a treatment were able to cope with diet challenge better than others. Another experiment was conducted to induce SARA in sheep through oral glucose drench (Penner et al., 2009). Although the dose of glucose was same for all sheep, mean rumen $\mathrm{pH}$ was higher for resistant animals compared with susceptible ones (5.97 vs. 5.57). These individual variations among animals within the treatment clearly demonstrate that ruminants markedly vary in the extent of tolerance to dietary factors that predispose them to acidosis. However, as the type and intensity of acidosis challenge was not same for the studies mentioned previously, it is not possible to compare variations in rumen $\mathrm{pH}$ response and severity of SARA among different types of animals.

The second objective of the present study was to identify factors that are related to cows tolerant and susceptible to high-grain diets. We found that the tolerant cows sorted feed to a less extent than the susceptible ones. Cows have been shown to selectively consume rations even when fed a TMR; they generally sort against long particles and for fine particles (Kononoff et al., 2003; Leonardi and Armentano, 2003; DeVries et al., 2007). The majority of previous studies evaluating sorting behavior of dairy cows focused on management factors, such as effects of feeding frequency and

Table 5. Feed refusal and sorting index between tolerant and susceptible cows

\begin{tabular}{|c|c|c|c|c|}
\hline Item & Tolerant & Susceptible & $\mathrm{SE}$ & $P$-value \\
\hline Feed refusal, $\mathrm{kg} / \mathrm{d}$ & 3.7 & 4.1 & 0.49 & 0.61 \\
\hline \multicolumn{5}{|l|}{ Sorting index ${ }^{1}$} \\
\hline$>19.0 \mathrm{~mm}$ & 97.9 & $87.6^{*}$ & 3.19 & 0.05 \\
\hline 19.0 to $8.0 \mathrm{~mm}$ & $97.3^{*}$ & 98.8 & 1.17 & 0.39 \\
\hline 8.0 to $1.18 \mathrm{~mm}$ & $102^{*}$ & $105^{*}$ & 0.91 & 0.05 \\
\hline$<1.18 \mathrm{~mm}$ & 101 & $104^{*}$ & 1.02 & 0.06 \\
\hline \multicolumn{5}{|l|}{ DMI, $\mathrm{kg} / \mathrm{d}$} \\
\hline$>19.0 \mathrm{~mm}$ & 4.29 & 3.33 & 0.32 & 0.07 \\
\hline $19.0-8.0 \mathrm{~mm}$ & 5.12 & 4.51 & 0.32 & 0.23 \\
\hline $8.0-1.18 \mathrm{~mm}$ & 8.73 & 7.79 & 0.48 & 0.22 \\
\hline$<1.18 \mathrm{~mm}$ & 3.51 & 3.14 & 0.21 & 0.26 \\
\hline
\end{tabular}

${ }^{1}$ Sorting index was calculated as the ratio of actual intake to predicted intake for particles retained on each sieve of the separator. A sorting index above 100 indicates sorting for particles, and a sorting index below 100 indicates sorting against particles (Leonardi and Armentano, 2003).

*Different from $100(P<0.05)$. 
Table 6. Comparison of chewing activity between tolerant and susceptible cows

\begin{tabular}{lcccc}
\hline Variable & Tolerant & Susceptible & SE & $P$-value \\
\hline Time, min/d & & & & \\
Eating & 223 & 220 & 13.7 & 0.87 \\
Ruminating & 544 & 610 & 33.7 & 0.21 \\
$\quad$ Total chewing & 768 & 830 & 32.8 & 0.22 \\
Time, min/kg of DMI & & & & \\
Eating & 10.3 & 12.0 & 0.70 & 0.14 \\
Ruminating & 25.4 & 33.2 & 2.35 & 0.05 \\
Total chewing & 35.8 & 45.1 & 2.65 & 0.04 \\
Time, min/kg of NDF & & & & \\
Eating & 40.3 & 46.7 & 2.72 & 0.14 \\
Ruminating & 99.4 & 130 & 9.05 & 0.05 \\
Total chewing & 140 & 176 & 10.1 & 0.04 \\
\hline
\end{tabular}

${ }^{1}$ The sum of eating time and ruminating time.

stocking density, and dietary factors, such as effects of DM content, forage content, and particle size of TMR. However, substantial individual variation in sorting behavior exists among animals, even those fed the same diet. Leonardi and Armentano (2003) indicated that although all cows generally sorted against long particles (retained on a sieve of 26.9-mm apertures), intake of long particles as a percentage of predicted intake was $<70 \%$ for 4 cows, between 71 and $80 \%$ for 11 cows, between 81 and $90 \%$ for 5 cows, and between 91 and $100 \%$ for 2 cows. One extreme cow even failed to consume any of the long particles of TMR. Leonardi et al., (2005) found similar animal variation in sorting; sorting index of long particles (retained on a sieve of 26.9-mm apertures) ranged from approximately 10 to 100 when a dry TMR $(89.9 \% \mathrm{DM})$ was offered. In another study, Leonardi and Armentano (2007) detected that the sorting index of the long particles were from 40 to 100 among 29 cows fed a diet containing 68\% DM. In the current study, we also found that sorting index of long particles (retained on a sieve of 19-mm apertures) ranged from 76.1 to 103.6, even though all cows were fed the same diet, and acidosis-susceptible cows sorted against long particles whereas the tolerant cows did not. The DM content of the experimental diet was $60.8 \%$ due to the high-concentrate content, whereas the typical TMR given to high-producing dairy cows ranges from 40 to $60 \%$ DM (Eastridge, 2006). The dry TMR used in the current study may have increased sorting behavior of animals, but the effect of DM content on sorting is not conclusive. It is commonly believed that addition of water to a dry TMR would bind particles together and make it harder for cows to sort (MillerCushon and DeVries, 2009). Leonardi et al. (2005) indicated a reduction in the extent of sorting against long particles when water was added to a dry TMR (DM reduced from 81 to $64 \%$ ). However, Miller-Cushon and DeVries (2009) found that sorting was increased when adding water to a TMR (reducing DM content from 58 to $48 \%$ ). The difference between these 2 studies may be explained by the difference in diet composition and DM content of the diets used. Felton and DeVries (2010) also found that greater amounts of water added to the TMR (DM of diets were 56.3, 50.8, and $44.1 \% \mathrm{DM}$ ) resulted in greater sorting against long-particle diets. Therefore, it is not clear whether the sorting behavior of animals fed a relatively dry TMR in the current study would be different from those fed a TMR with less DM content.

Cows sorting TMR may create problems because sorting not only reduces the particle size of the diet consumed, but also reduces NDF intake, as the longer

Table 7. Comparisons of milk yield and milk composition between tolerant and susceptible cows

\begin{tabular}{lcccc}
\hline Variable & Tolerant & Susceptible & SE & $P$-value \\
\hline Yield, kg/d & & & & \\
Milk & 28.6 & 24.2 & 3.58 & 0.41 \\
Fat & 0.93 & 0.67 & 0.16 & 0.30 \\
CP & 1.03 & 0.87 & 0.11 & 0.32 \\
Lactose & 1.26 & 1.11 & 0.16 & 0.54 \\
Milk composition & & & & \\
Fat, \% & 3.22 & 2.73 & 0.33 & 0.33 \\
CP, \% & 3.64 & 3.60 & 0.14 & 0.84 \\
Lactose, \% & 4.42 & 4.59 & 0.13 & 0.40 \\
MUN, mg/dL & 12.8 & 8.60 & 0.97 & 0.02 \\
\hline
\end{tabular}


Table 8. Comparison of plasma blood metabolite and hormone concentration between tolerant and susceptible cows

\begin{tabular}{lcccc}
\hline Variable & Tolerant & Susceptible & SE & $P$-value \\
\hline Glucose, $\mathrm{mg} / \mathrm{dL}$ & 70.2 & 67.0 & 3.86 & 0.57 \\
BHBA, mg/dL & 7.73 & 9.37 & 1.73 & 0.52 \\
NEFA, mEq/L & 64.9 & 74.9 & 4.01 & 0.12 \\
Insulin, $\mu \mathrm{IU} / \mathrm{dL}$ & 21.2 & 19.8 & 5.04 & 0.85 \\
\hline
\end{tabular}

particles of TMR contain more NDF than the rest of the ration (Leonardi and Armentano, 2003). Excessive sorting of a TMR can result in overconsumption of rapidly fermentable carbohydrates (relative to the anticipated intake) and refusal of physically effective fiber, which is expected to increase VFA production and decrease acid neutralization by reduced chewing (Cook et al., 2004; DeVries et al., 2008). Therefore, sorting behavior may be one of the factors that increase the risk of SARA. DeVries et al. (2008) found that when early-lactation cows were fed a low-forage diet ( $45 \%$ forage), their sorting activity was related to ruminal $\mathrm{pH}$ : the more cows sorted for medium and short particles, the lower their nadir, mean, and maximum ruminal $\mathrm{pH}$ were. In the current study, the tolerant cows tended to consume more long particles $(>19.0 \mathrm{~mm})$ than the susceptible cows (Table 5). In addition, sorting index of long particles was positively correlated with minimum ruminal $\mathrm{pH}(\mathrm{r}=0.60, P=0.01$; Figure 1$)$ and negatively correlated with acidosis index $(\mathrm{r}=-0.64, P<0.01)$. Therefore, the variation in susceptibility to high-grain diets among animals might be related to the variation in sorting against long particles, and more work needs to be done to confirm these findings.

The current study showed the relationship between sorting behavior and rumen $\mathrm{pH}$, but no differences were observed in ruminal $\mathrm{pH}$ in some of the previous studies where significant ration sorting was identified (Kononoff and Heinrichs, 2003; Kononoff et al., 2003; Leonardi et al., 2005; Bhandari et al., 2008; Maulfair et al., 2010). In addition, Maulfair et al. (2010) detected that rumen $\mathrm{pH}$ tended to increase quadratically $(P$ $=0.07)$ with increased sorting against long particles. Moreover, a few studies indicated that cows sorted for long feed particles as an attempt to meet physically effective fiber requirements when cows experience low rumen pH (Keunen et al., 2002; Beauchemin and Yang, 2005; DeVries et al., 2008), which means that cows may change their sorting behavior to attenuate the effects of acidosis. Therefore, the speculation that ration sorting decreases ruminal $\mathrm{pH}$ is not conclusively supported, and the reasons are not clear. However, effects of sorting on rumen $\mathrm{pH}$ might have been confounded by dietary (treatment) effects, and the extent of sorting in these studies might not be severe enough to pose the potential effect on rumen pH. DeVries et al. (2011) speculated that the risk of SARA would be much greater when sorting against long particles is more substantial (i.e., $20-30 \%$ refusal of long particles).

We found that cows that tolerant to a high-grain diet sorted feed to a lesser extent than the susceptible cows, and, as such, we expected that the tolerant cows would chew more. It has been suggested that chewing time is a good indicator of rumen health because chewing stimulates salivary buffer secretion (Allen, 1997), which helps neutralization of acids produced from fermentation. Chewing activity is highly influenced by particle length and chemical NDF concentration of the diets (Mertens, 1997; Zebeli et al., 2008). Balch (1971)
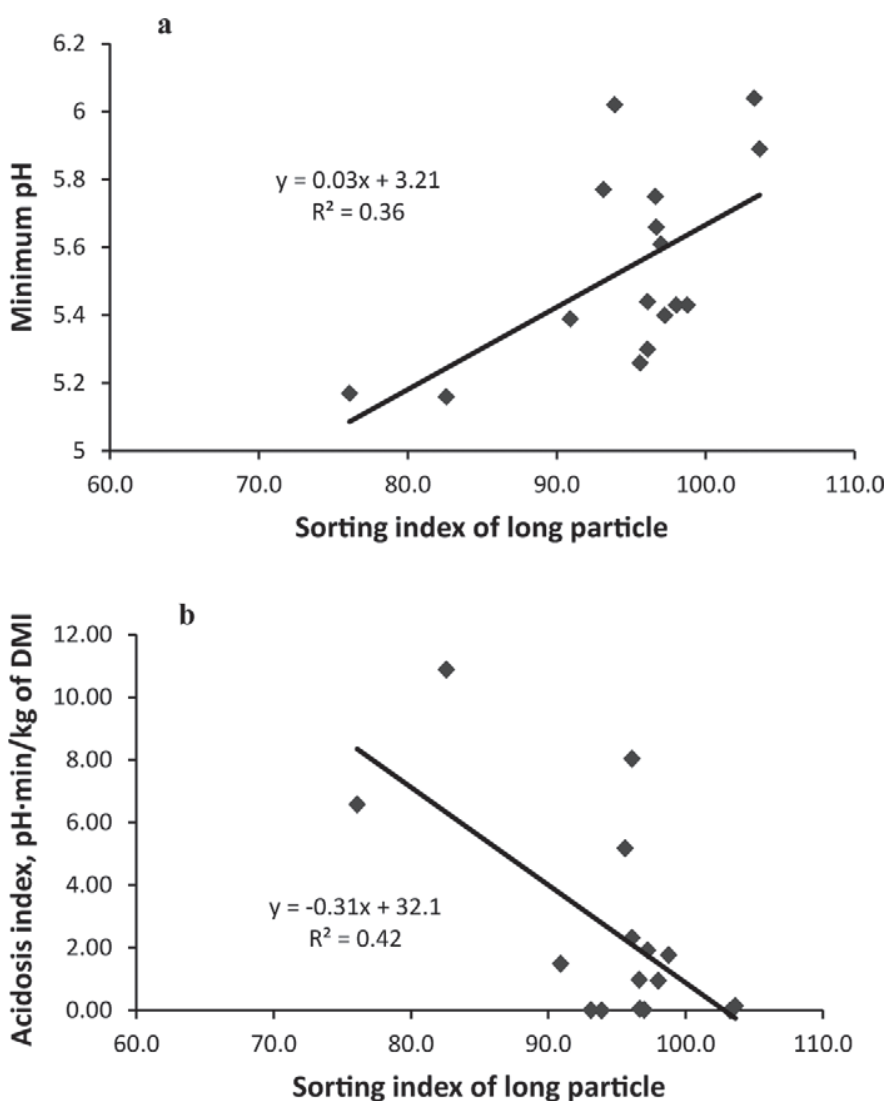

Figure 1. Relationship between sorting index of long particles (retained on a sieve of $19-\mathrm{mm}$ apertures) with (a) minimum ruminal $\mathrm{pH}$ $(P=0.01)$, and (b) acidosis index $(P<0.01)$. 
proposed using total time spent chewing per kilogram of DMI as an indicator of the physical property of the diet to minimize the confounding effects of different feed intakes. In the current study, we expected that the tolerant cows would have longer chewing time per unit of DMI than the susceptible cows; however, we found the opposite results. Total chewing time was 768 $\mathrm{min} / \mathrm{d}$ and total chewing time per NDF intake was 140 $\mathrm{min} / \mathrm{kg}$ for tolerant cows, whereas total chewing time was $830 \mathrm{~min} / \mathrm{d}$ and total chewing time per NDF intake was $176 \mathrm{~min} / \mathrm{kg}$ for susceptible cows. Chewing time measured in the current study was longer, regardless the group, than that reported in previous studies; Yang and Beauchemin (2007) reported total chewing was 655 $\mathrm{min} / \mathrm{d}$ and $101.3 \mathrm{~min} / \mathrm{kg}$ of NDF intake when diet forage-to-concentrate ratio was 35 to 65 . In another study conducted later (Yang and Beauchemin, 2009), similar total chewing time was found $(657 \mathrm{~min} / \mathrm{d}$ and $102 \mathrm{~min} /$ $\mathrm{kg}$ of NDF intake) for cows fed the diet with a similar forage-to-concentrate ratio. Longer chewing time for the current study might be partly due to different methods of chewing activity monitoring (visual observation vs. automated data collection). In addition, in the present study, the data collection period for chewing behavior was limited to a relatively short period ( $1 \mathrm{~d})$. Dado and Allen (1994) indicated that considerable day-to-day variation exists in feeding behavior data within cows. As such, the differences observed in chewing activities between 2 groups need to be interpreted with caution. Nonetheless, our findings provided no evidence to attribute higher rumen $\mathrm{pH}$ of the tolerant cows to the difference in chewing activity.

A couple of possible explanations exist for our observation that tolerant cows chewed less than susceptible cows. First, it may be possible that cows possess an adaptive response to the reduction in rumen $\mathrm{pH}$. Previous studies have shown that cows would increase the amount of rumination needed per unit of NDF when rumen $\mathrm{pH}$ is low (Beauchemin, 1991; Beauchemin et al., 1994); likewise, chewing time per unit of NDF intake was less for high- than for low-NDF diets (Oba and Allen, 2000; Yang et al., 2001; Maulfair and Heinrichs, 2013), which suggests that effectiveness of forage in promoting chewing increases when rumen $\mathrm{pH}$ becomes lower. In the current study, susceptible cows had a lower ruminal $\mathrm{pH}$. Therefore, as an adaptive response, chewing time per unit of DMI might have increased to attenuate the reduction in ruminal $\mathrm{pH}$ by increased saliva secretion or enhanced particulate and fluid movement from the rumen (Krause et al., 2002). DeVries et al. (2009) dosed $4 \mathrm{~kg}$ of ground barley and wheat into the rumen to induce ruminal acidosis before feeding TMR (45:55 of forage to concentrate ratio). Those authors found that rumination time was longer for animals experiencing more severe SARA as a result of the grain dosage. Therefore, although the particle length and chemical NDF concentration of the diets influence chewing activity, additional metabolic mechanisms regulating chewing activity need to be identified (Oba and Allen, 2000).

The second possibility for greater chewing time per unit of DMI for the susceptible cows is that lower rumen $\mathrm{pH}$ decreased fiber digestibility in the rumen (Russell and Wilson, 1996; Beauchemin, 2000) and increased the retention time of ruminal digesta for susceptible cows. Expected greater digesta mass in the rumen of susceptible cows may have stimulated chewing activity. Grant et al. (1995) found that total chewing time per kilogram of NDF intake was lower for cows fed brown midrib sorghum silage compared with those fed normal sorghum silage. Brown midrib sorghum silage was greater in NDF degradability than in normal sorghum silage. Therefore, enhanced NDF degradability of forage might have decreased its physical effectiveness at stimulating chewing due to a faster disappearance rate of digesta in the rumen. Oba and Allen (2000) also suggested that forage NDF degradability might affect chewing activities unless a critical amount digesta in the rumen is maintained. In the current study, rate of fiber digestion and digesta mass in the rumen were not determined, but the possibility that low rumen $\mathrm{pH}$ increased chewing activities via a greater rumen fill cannot be excluded as a reason for greater chewing activities for the susceptible cows.

The variation in the susceptibility to high-grain diets among animals is a concern because dairy diets are often formulated for the average animal on farms, and the susceptible cows may experience SARA whereas the average animal does not. Therefore, identifying tolerant and susceptible cows and adjusting nutritional management accordingly may reduce this nutritional disorder. In the current study, ruminally canulated cows were used, and the tolerant and susceptible cows were identified by measuring rumen $\mathrm{pH}$. However, it is not practical to measure rumen $\mathrm{pH}$ for numbers of cows on farms. Therefore, it is necessary to evaluate an easy indicator of rumen $\mathrm{pH}$ to identify the tolerant and susceptible cows. We expected milk fat content might be the noninvasive indicator, but milk fat content did not differ between the 2 groups in the current study. Some previous studies also reported no effect of ruminal $\mathrm{pH}$ on milk fat concentration and indicated that milk fat depression does not always accompany SARA (Keunen et al., 2002; Cottee et al., 2004; Gozho et al., 2007). Those authors suggested that the inconsistent response in milk fat in experimentally induced SARA may be related to the duration of SARA; short durations of SARA may not affect milk fat content (Krause and 


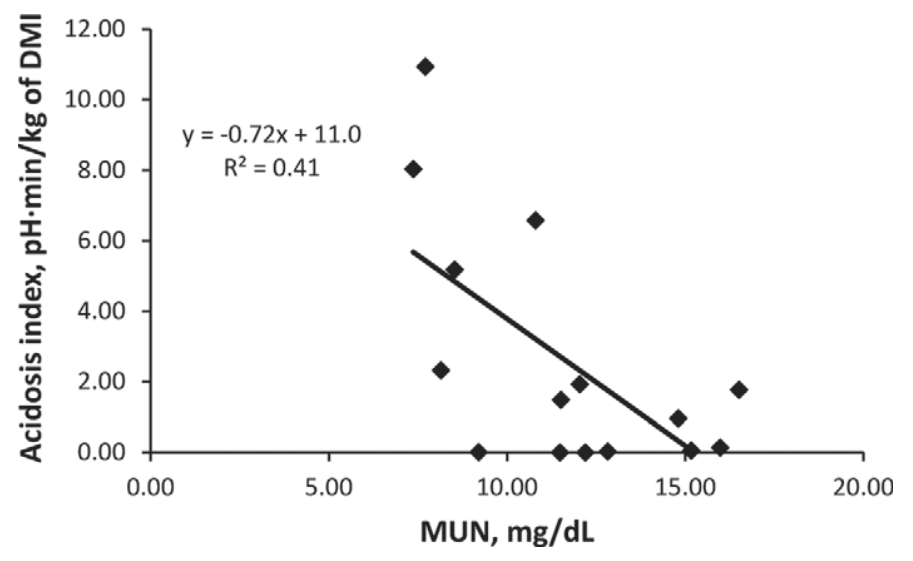

Figure 2. Relationship between acidosis index with MUN concentration $(P=0.01)$.

Oetzel, 2005). Because microbial responses to ruminal acidosis may be slow, multiple acidotic insults are necessary before ruminal biohydrogenation is inhibited to cause milk fat depression (Oetzel, 2007). However, in the current study, cows were fed the high-grain diet for 21 d. As such, the duration of the SARA was expected to be long enough and may not be a possible explanation for this case. However, Oetzel (2007) indicated that the relationship between SARA and milk fat depression is inconsistent and influenced more by other factors, and suggested that many cows and herds with substantially depressed ruminal pH could have no milk fat depression at all. In the current study, we observed a large numerical difference in milk fat concentration between the 2 groups (3.22 vs. 2.73), but we could not detect this as a significant difference due to a substantial variation within groups $(\mathrm{SE}=0.33)$. This indicates that other unidentified factors, besides rumen $\mathrm{pH}$, affected milk fat content, and that milk fat content may not be a sensitive indicator to identify cows that are tolerant or susceptible to high-grain diets. In addition, fat content of tolerant cows was $3.59 \%$ immediately before the current study when cows were fed a high-forage diet (60:40 forage-to-concentrate ratio), which indicated that the high-grain diet fed during the current study decreased milk fat content to some extent even for the tolerant cows.

However, we found that the tolerant cows had higher MUN concentration than the susceptible ones. In addition, a negative correlation was observed between MUN and acidosis index $(\mathrm{r}=-0.64, P=0.01$; Figure 2). Milk urea nitrogen concentration did not differ between the 2 groups before the start of experiment when all cows were fed a diet containing $60 \%$ forage on a DM basis. Therefore, MUN might be potentially used as an indicator to identify tolerant and susceptible cows fed high-grain diets. Concentration of MUN is a good predictor of urinary $\mathrm{N}$ excretion and the efficiency of protein utilization in dairy cows (Gustafsson and Palmquist, 1993; Kohn et al., 2002). It has been indicated that MUN can be affected by nutritional factors, such as dietary CP content, ruminally fermentable OM, the ratio of dietary CP to energy, and the extent of CP degradation in the rumen (Carlsson et al., 1995; Hof et al., 1997; NRC, 2001). In addition, it is affected by nonnutritional factors, such as DIM, parity, season, and milking frequency (Carlsson et al., 1995; Hof et al., 1997). Also, MUN concentration is affected by unidentified animal factors (Wattiaux et al., 2005; Cyriac et al., 2008; Rius et al., 2010). In the current study, all cows were fed the same diet and, most likely, were in positive balance for all nutrients, including energy and protein. Due to the numerical difference in DMI, the tolerant cows had $445 \mathrm{~g}$ more CP intake; higher MUN and rumen $\mathrm{NH}_{3}$ appear to be attributable to the difference in CP intake. However, the difference in CP intake between the groups was not significant. In addition, before the start of experiment, when cows were fed a $60 \%$ forage diet, the tolerant cows and susceptible cows had similar ruminal $\mathrm{NH}_{3}$ (9.37 vs. $10.9 \mathrm{mg} / \mathrm{dL}$, respectively; $P=0.56)$ and MUN concentrations (12.5 vs. $11.6 \mathrm{mg} / \mathrm{dL}$, respectively; $P=0.54)$, although DMI was numerically greater for the tolerant cows (23.9 vs. $19.6 \mathrm{~kg} / \mathrm{d} ; P=0.14)$. Therefore, the numerical difference in $\mathrm{CP}$ intake may not be the exclusive reason that tolerant cows had higher MUN and rumen $\mathrm{NH}_{3}$ when cows were fed the high-grain diet. Schlau et al. (2012) suggested that higher ruminal $\mathrm{pH}$ for acidosis-resistant steers is partly due to lower VFA production. Greater MUN and ruminal $\mathrm{NH}_{3}$ concentrations for the tolerant cows in the current study may indicate that $\mathrm{OM}$ fermentation is lower for them even if the same diet was fed. However, we did not measure the rate of VFA production or OM fermented in the rumen in the current study; as such, further research is warranted to confirm this preliminary finding and identify if MUN could be used as a noninvasive indicator to identify tolerant and susceptible cows on farms.

\section{CONCLUSIONS}

A substantial variation exists in the severity of SARA among lactating dairy cows when fed the same highgrain diet. Cows that are tolerant to high-grain diets sorted to a lesser extent compared with susceptible cows. However, tolerant cows may not necessarily have longer chewing time than susceptible cows. In addition, MUN concentration, rather than milk fat content, might be potentially used as a noninvasive indicator to identify cows that are tolerant to high-grain diets on farm. 


\section{ACKNOWLEDGMENTS}

This study was supported by Alberta Milk (Edmonton, AB, Canada) and Natural Sciences and Engineering Research Council of Canada (Ottawa, ON, Canada). The authors thank Y. Sun, J. Haisan, M. Lu, C. Kent-Dennis and A. Ruiz-Sanchez (all of University of Alberta, Edmonton, AB, Canada) for their assistance with animal handing and sample collections.

\section{REFERENCES}

Allen, M. S. 1997. Relationship between fermentation acid production in the rumen and the requirement for physically effective fiber. J. Dairy Sci. 80:1447-1462.

AOAC International. 2002. Official Methods of Analysis. 17th ed. AOAC International, Gaithersburg, MD.

Balch, C. C. 1971. Proposal to use time spent chewing as an index of the extent to which diets for ruminants prossess the physical property of fibrousness characteristic of roughages. Br. J. Nutr. 26:383-392.

Beauchemin, K. A. 1991. Effects of dietary neutral detergent fiber concentration and alfalfa hay quality on chewing, rumen function, and milk production. J. Dairy Sci. 74:3140-3151.

Beauchemin, K. A. 2000. Managing rumen fermentation in barleybased diets: Balance between high production and acidosis. Adv. Dairy Technol. 12:109-125.

Beauchemin, K. A., B. I. Farr, L. M. Rode, and G. B. Schaalje. 1994. Effects of alfalfa silage chop length and supplementary long hay on chewing and milk production of dairy cows. J. Dairy Sci. 77:1326-1339.

Beauchemin, K. A., and W. Z. Yang. 2005. Effects of physically effective fiber on intake, chewing activity, and ruminal acidosis for dairy cows fed diets based on corn silage. J. Dairy Sci. 88:2117-2129.

Beauchemin, K. A., W. Z. Yang, and L. M. Rode. 2003. Effects of particle size of alfalfa-based dairy cow diets on chewing activity, ruminal fermentation, and milk production. J. Dairy Sci. 86:630-643.

Bhandari, S. K., S. Li, K. H. Ominski, K. M. Wittenberg, and J. C. Plaizier. 2008. Effects of the chop lengths of alfalfa silage and oat silage on feed intake, milk production, feeding behavior, and rumen fermentation of dairy cows. J. Dairy Sci. 91:1942-1958.

Brown, M. S., C. Krehbiel, M. Galyean, M. Remmenga, J. Peters, B. Hibbard, J. Robinson, and W. Moseley. 2000. Evaluation of models of acute and subacute acidosis on dry matter intake, ruminal fermentation, blood chemistry, and endocrine profiles of beef steers. J. Anim. Sci. 78:3155-3168.

Carlsson, J., J. Bergstrom, and B. Pehrson. 1995. Variations with breed, age, season, yield, stage of lactation, and herd in the concentration of urea in bulk milk and individual cow's milk. Acta Vet. Scand. 36:245-254.

Church, D. C. 1988. Salivary function and production. Pages 117-124 in The Ruminant Animal Digestive Physiology and Nutrition. D. C. Church, ed. Prentice Hall, Englewood Cliffs, NJ.

Cook, N. B., K. V. Nordlund, and G. R. Oetzel. 2004. Environmental influences on claw horn lesions associated with laminitis and subacute ruminal acidosis in dairy cows. J. Dairy Sci. 87:E36-E46.

Cottee, G., I. Kyriazakis, T. M. Widowski, M. I. Lindinger, J. P. Cant, T. F. Duffield, V. R. Osborne, and B. W. McBride. 2004. The effects of subacute ruminal acidosis on sodium bicarbonatesupplemented water intake for lactating dairy cows. J. Dairy Sci. $87: 2248-2253$.

Cyriac, J., A. G. Rius, M. L. McGilliard, R. E. Pearson, B. J. Bequette, and M. D. Hanigan. 2008. Lactation performance of midlactation dairy cows fed ruminally degradable protein at concentrations lower than National Research Council recommendations. J. Dairy Sci. 91:4704-4713.
Dado, R. G., and M. S. Allen. 1994. Variation in and relationships among feeding, chewing, and drinking variables for lactating dairy cows. J. Dairy Sci. 77:132-144.

DeVries, T. J., K. A. Beauchemin, F. Dohme, and K. S. SchwartzkopfGenswein. 2009. Repeated ruminal acidosis challenges in lactating dairy cows at high and low risk for developing acidosis: Feeding, ruminating, and lying behavior. J. Dairy Sci. 92:5067-5078.

DeVries, T. J., K. A. Beauchemin, and M. A. G. von Keyserlingk. 2007. Dietary forage concentration affects the feed sorting behavior of lactating dairy cows. J. Dairy Sci. 90:5572-5579.

DeVries, T. J., F. Dohme, and K. A. Beauchemin. 2008. Repeated ruminal acidosis challenges in lactating dairy cows at high and low risk for developing acidosis: Feed sorting. J. Dairy Sci. 91:39583967.

DeVries, T. J., L. Holtshausen, M. Oba, and K. A. Beauchemin. 2011. Effect of parity and stage of lactation on feed sorting behavior of lactating dairy cows. J. Dairy Sci. 94:4039-4045.

Eastridge, M. L. 2006. Major advances in applied dairy cattle nutrition. J. Dairy Sci. 89:1311-1323.

Enemark, J. M. D., R. J. Jorgensen, and N. B. Kristensen. 2004. An evaluation of parameters for the detection of subclinical rumen acidosis in dairy herds. Vet. Res. Commun. 28:687-709.

Fairfield, A. M., J. C. Plaizier, T. F. Duffield, M. I. Lindinger, R. Bagg, P. Dick, and B. W. McBride. 2007. Effects of a prepartum administration of a monensin controlled release capsule on rumen $\mathrm{pH}$, feed intake, and milk production of transition dairy cows. J. Dairy Sci. 90:937-945

Fawcett, J. K., and J. E. Scott. 1960. A rapid and precise method for the determination of urea. J. Clin. Pathol. 13:156-159.

Felton, C. A., and T. J. DeVries. 2010. Effect of water addition to a total mixed ration on feed temperature, feed intake, sorting behavior, and milk production of dairy cows. J. Dairy Sci. 93:2651-2660.

Garret, E. F., K. V. Nordlund, W. J. Goodger, and G. R. Oetzel. 1997. A cross-sectional field study investigating the effect of periparturient dietary management on ruminal $\mathrm{pH}$ in early lactation dairy cows. J. Dairy Sci. 80(Suppl.1):169. (Abstr.)

Gozho, G. N., D. O. Krause, and J. C. Plaizier. 2007. Ruminal lipopolysaccharide concentration and inflammatory response during grain induced subacute ruminal acidosis in dairy cows. J. Dairy Sci. 90:856-866.

Grant, R. J., S. G. Haddad, K. J. Moore, and J. F. Pedersen. 1995. Brown midrib sorghum silage for midlactation dairy cows. J. Dairy Sci. 78:1970-1980.

Gustafsson, A. H., and D. L. Palmquist. 1993. Diurnal variation of rumen ammonia, serum urea, and milk urea in dairy cows at high and low yields. J. Dairy Sci. 76:475-484.

Hof, G., M. D. Vervoorn, P. L. Lenaers, and S. Tamminga. 1997. Milk urea nitrogen as a tool to monitor the protein nutrition of dairy cows. J. Dairy Sci. 80:3333-3340.

Keunen, J. E., J. C. Plaizier, I. Kyriazakis, T. F. Duffield, T. M. Widowski, M. I. Lindinger, and B. W. McBride. 2002. Effects of a subacute ruminal acidosis model on the diet selection of dairy cows. J. Dairy Sci. 85:3304-3313.

Khafipour, E., D. O. Krause, and J. C. Plaizier. 2007. Induction of subacute ruminal acidosis (SARA) by replacing alfalfa hay with alfalfa pellets does not stimulate inflammatory response in lactating dairy cows. J. Dairy Sci. 90(Suppl. 1):654. (Abstr.)

Khafipour, E., D. O. Krause, and J. C. Plaizier. 2009. A grain-based subacute ruminal acidosis challenge causes translocation of lipopolysaccharide and triggers inflammation. J. Dairy Sci. 92:10601070.

Khorasani, G. R., E. K. Okine, and J. J. Kennelly. 1996. Forage source alters nutrient supply to the intestine without influencing milk yield. J. Dairy Sci. 79:862-872.

Kleen, J. L., G. A. Hooijer, J. Rehage, and J. P. Noordhuizen. 2003. Subacute ruminal acidosis (SARA): A review. J. Vet. Med. A Physiol. Pathol. Clin. Med. 50:406-414.

Kohn, R. A., K. F. Kalscheur, and E. Russek-Cohen. 2002. Evaluation of models to estimate urinary nitrogen and expected milk urea nitrogen. J. Dairy Sci. 85:227-233. 
Kononoff, P. J., and A. J. Heinrichs. 2003. The effect of corn silage particle size and cottonseed hulls on cows in early lactation. J. Dairy Sci. 86:2438-2451.

Kononoff, P. J., A. J. Heinrichs, and H. A. Lehman. 2003. The effect of corn silage particle size on eating behavior, chewing activities, and rumen fermentation in lactating dairy cows. J. Dairy Sci. 86:3343-3353.

Krause, K. M., D. K. Combs, and K. A. Beauchemin. 2002. Effects of forage particle size and grain fermentability in midlactation cows. II. Ruminal pH and chewing activity. J. Dairy Sci. 85:1947-1957.

Krause, K. M., D. K. Combs, and K. A. Beauchemin. 2003. Effects of increasing levels of refined cornstarch in the diet of lactating dairy cows on performance and ruminal pH. J. Dairy Sci. 86:1341-1353.

Krause, K. M., and G. R. Oetzel. 2005. Inducing subacute ruminal acidosis in lactating dairy cows. J. Dairy Sci. 88:3633-3639.

Lammers, B. P., D. R. Buckmaster, and A. J. Heinrichs. 1996. A simple method for the analysis of particle sizes of forage and total mixed rations. J. Dairy Sci. 79:922-928.

Leonardi, C., and L. E. Armentano. 2003. Effect of quantity, quality, and length of alfalfa hay on selective consumption by dairy cows. J. Dairy Sci. 86:557-564.

Leonardi, C., and L. E. Armentano. 2007. Short communication: Feed selection by dairy cows fed individually in a tie-stall or as a group in a free-stall barn. J. Dairy Sci. 90:2386-2389.

Leonardi, C., F. Giannico, and L. E. Armentano. 2005. Effect of water addition on selective consumption (sorting) of dry diets by dairy cattle. J. Dairy Sci. 88:1043-1049.

Maulfair, D. D., and A. J. Heinrichs. 2013. Effects of varying forage particle size and fermentable carbohydrates on feed sorting, ruminal fermentation, and milk and component yields of dairy cows. J. Dairy Sci. 96:3085-3097.

Maulfair, D. D., G. I. Zanton, M. Fustini, and A. J. Heinrichs. 2010. Effect of feed sorting on chewing behavior, production, and rumen fermentation in lactating dairy cows. J. Dairy Sci. 93:4791-4803.

Mertens, D. R. 1997. Creating a system for meeting the fiber requirements of dairy cows. J. Dairy Sci. 80:1463-1481.

Miller-Cushon, E. K., and T. J. DeVries. 2009. Effect of dietary dry matter concentration on the sorting behavior of lactating dairy cows fed a total mixed ration. J. Dairy Sci. 92:3292-3298.

Nagaraja, T. G., and K. F. Lechtenberg. 2007. Acidosis in feedlot cattle. Vet. Clin. North Am. Food Anim. Pract. 23:333-350.

Nocek, J. E. 1997. Bovine acidosis: Implications on laminitis. J. Dairy Sci. 80:1005-1028

NRC. 2001. Nutrient Requirements of Dairy Cattle. Natl. Acad. Sci., Washington, DC

Oba, M., and M. S. Allen. 2000. Effects of brown midrib 3 mutation in corn silage on productivity of dairy cows fed two concentrations of dietary neutral detergent: 2. Chewing activities. J. Dairy Sci. 83:1342-1349.

Oetzel, G. R. 2003. Subacute ruminal acidosis in dairy cattle. Adv. Dairy Technol. 15:307-317.

Oetzel, G. R. 2007. Subacute ruminal acidosis in dairy herds: Physiology, pathophysiology, milk fat responses, and nutritional manage- ment. Preconvention Seminar 7A. Am. Assoc. Bovine Pract. 40th Annu. Conf.

Penner, G. B., J. R. Aschenbach, G. Gaebel, R. Rackwitz, and M. Oba. 2009. Epithelial capacity for apical uptake of short chain fatty acids is a key determinant for intraruminal $\mathrm{pH}$ and the susceptibility to subacute ruminal acidosis in sheep. J. Nutr. 139:1714-1720.

Penner, G. B., K. A. Beauchemin, and T. Mutsvangwa. 2006. An evaluation of the accuracy and precision of a stand-alone submersible continuous ruminal pH measurement system. J. Dairy Sci. $89: 2132-2140$

Penner, G. B., K. A. Beauchemin, and T. Mutsvangwa. 2007. The severity of ruminal acidosis in primiparous Holstein cows during the periparturient period. J. Dairy Sci. 90:365-375.

Rius, A. G., M. L. McGilliard, C. A. Umberger, and M. D. Hanigan. 2010. Interactions of energy and predicted metabolizable protein in determining nitrogen efficiency in the lactating dairy cow. J. Dairy Sci. 93:2034-2043.

Russell, J. B., and D. B. Wilson. 1996. Why are ruminal cellulolytic bacteria unable to digest cellulose at low pH? J. Dairy Sci 79:1503-1509.

Schlau, N., L. L. Guan, and M. Oba. 2012. The relationship between rumen acidosis resistance and expression of genes involved in regulation of intracellular $\mathrm{pH}$ and butyrate metabolism of ruminal epithelial cells in steers. J. Dairy Sci. 95:5866-5875.

Stone, W. C. 1999. The effect of subclinical acidosis on milk components. Pages 40-46 in Cornell Nutrition Conference for Feed Manufacturers. Cornell Univ., Ithaca, NY.

Stone, W. C. 2004. Nutritional approaches to minimize subacute ruminal acidosis and laminitis in dairy cattle. J. Dairy Sci. 87:E13E26.

Wattiaux, M. A., E. V. Nordheim, and P. Crump. 2005. Statistical evaluation of factors and interactions affecting dairy herd improvement milk urea nitrogen in commercial Midwest dairy herds. J. Dairy Sci. 88:3020-3035.

Yang, W. Z., and K. A. Beauchemin. 2007. Altering physically effective fiber intake through forage proportion and particle length: Chewing and ruminal pH. J. Dairy Sci. 90:2826-2838.

Yang, W. Z., and K. A. Beauchemin. 2009. Increasing physically effective fiber content of dairy cow diets through forage proportion versus forage chop length: Chewing and ruminal pH. J. Dairy Sci. 92:1603-1615.

Yang, W. Z., K. A. Beauchemin, and L. M. Rode. 2001. Effects of grain processing, forage to concentrate ratio, and forage particle size on rumen $\mathrm{pH}$ and digestion by dairy cows. J. Dairy Sci. 84:2203-2216

Zebeli, Q., J. Dijkstra, M. Tafaj, H. Steingass, B. N. Ametaj, and W. Drochner. 2008. Modeling the adequacy of dietary fiber in dairy cows based on the responses of ruminal $\mathrm{pH}$ and milk fat production to composition of the diet. J. Dairy Sci. 91:2046-2066.

Zhang, S. Z., G. B. Penner, W. Z. Yang, and M. Oba. 2010. Effects of partially replacing barley silage or barley grain with dried distillers grains with solubles on rumen fermentation and milk production of lactating dairy cows. J. Dairy Sci. 93:3231-3242. 